\title{
MODEL SINERGI UNSUR PENTAHELIKS PARIWISATA DALAM PENGELOLAAN DESTINASI WISATA KOTA PAREPARE DAN KABUPATEN BONE
}

\author{
Ilham Junaid \\ Manajemen Pariwisata, Politeknik Pariwisata Makassar \\ E-mail: illank77@yahoo.co.id
}

\begin{abstract}
ABSTRAK. Menteri Pariwisata Republik Indonesia menggunakan istilah pentaheliks pariwisata yang terdiri dari academics, business, government, community, media (ABGCM) untuk mendorong keterlibatan stakeholder dalam program pengembangan destinasi wisata. Namun, belum terdapat data empiris mengenai bagaimana sinergi yang terbangun antara unsur pentaheliks pariwisata di Sulawesi Selatan. Karena itu, dibutuhkan model sinergi yang dapat menjadi panduan dalam mengelola potensi pariwisata daerah dalam menunjang tercapainya destinasi unggulan. Tujuan penelitian ini adalah 1) mengidentifikasi kondisi faktual sinergi yang terbangun dan faktor-faktor yang menghambat sinergi unsur pentaheliks pariwisata; 2) mengusulkan model yang dapat diterapkan dalam pengelolaan destinasi wisata dalam perspektif sinergi pentaheliks pariwisata. Penelitian dilaksanakan di Kota Parepare dan Kabupaten Bone, Provinsi Sulawesi Selatan pada 2017 dengan metode pengumpulan data kualitatif melalui wawancara dan participant observation. Penelitian ini memanfaatkan konsep stakeholder dalam menganalisis data penelitian. Hasil penelitian menunjukkan bahwa sinergi pentaheliks pariwisata telah terbangun meskipun program kerja bidang pariwisata lebih didominasi oleh pemerintah daerah. Keterlibatan pentaheliks pariwisata sangat dibutuhkan untuk mendukung program pengembangan pariwisata daerah. Faktor-faktor seperti implementasi otonomi daerah, kurangnya pemahaman teknologi dan pariwisata oleh beberapa pentaheliks pariwisata serta lemahnya upaya kreatif dan inovatif di bidang pariwisata menjadi tantangan dalam pengelolaan destinasi wisata. Penelitian ini merekomendasikan tiga model manajemen destinasi wisata yakni implementasi tata kelola destinasi wisata (DMO) model pemerintah, model kawasan pariwisata percontohan dan strategi atau model go digital.
\end{abstract}

Kata kunci: Kota Parepare; Kabupaten Bone; sinergi; pentaheliks pariwisata; manajemen destinasi

\section{MODELS OF SINERGY FOR DESTINATION MANAGEMENT: A STUDY AT PAREPARE CITY AND BONE REGENCY}

\begin{abstract}
The Minister of Tourism, Republic of Indonesia uses the term 'pentaheliks of tourism' (academics, business, government, community and media) to encourage the involvement of stakeholders in tourism. However, there is not any empirical data on the synergy among the tourism stakeholders in South Sulawesi Province, Indonesia. Hence, model of synergy is required to strengthen relationship among the stakeholders and to support the management of tourism resources for superior tourism destination. The aims of this research are 1) to identify the actual condition of synergy among the 'pentaheliks pariwisata' and factors that constraint the synergy; 2) recommend models that may be implemented in the management of tourism destination under the framework of stakeholder synergy. This research employed qualitative methods through interviews, participant observation which was done in 2017 in Parepare city and Bone regency. This research utilises the concept of stakeholders in examining the conduct of tourism in the research area. The research reveals that synergy among the 'pentaheliks of tourism' has been implemented although the tourism programs are mostly managed by the local board of tourism. Efforts have been done by tourism pentaheliks, however, factors such as the implementation of regional autonomy, lack of understanding on tourism and information technology as well as lack of innovative efforts by the staff at the local board of tourism potentially constraint the development of tourism destination. This paper recommends three models for destination management including the implementation of destination management organisation on the government-based approach, tourism zone as a model of tourism attraction and go digital approach.
\end{abstract}

Key words: Parepare city; Bone regency; synergy; pentaheliks; destination management

\section{PENDAHULUAN}

Pemerintah Republik Indonesia melalui Kementerian Pariwisata menjadikan pariwisata sebagai salah satu sektor utama pengembangan nasional melalui target kunjungan 20 juta wisatawan mancanegara pada 2019. Pariwisata menjadi sektor unggulan yang diharapkan diikuti oleh pemerintah di daerah di seluruh wilayah Indonesia. Daerah-daerah di Indonesia memiliki potensi pariwisata yang diharapkan mampu memberikan manfaat positif bagi masyarakat melalui kegiatan pariwisata.

Target pemerintah tersebut tidak hanya menjadi tugas sekelompok anggota masyarakat, tetapi melibatkan berbagai unsur sehingga dibutuhkan sinergi antara berbagai kelompok masyarakat yang ada di suatu wilayah geografis atau destinasi wisata. Menteri Pariwisata Republik Indonesia menekankan pentingnya target pariwisata dalam lima tahun ke depan yakni kenaikan dua kali lipat dengan kontribusi PDB nasional sebesar 8\% dengan devisa sebesar Rp. 280 triliun. Kunjungan wisatawan yang meningkat sebagaimana yang ditargetkan tersebut diharapkan mampu mendorong ketersediaan lapangan kerja bidang pariwisata sebanyak 13 juta orang. Hal ini dimaknai sebagai pentingnya melibatkan berbagai unsur yang ada untuk membantu tercapainya sasaran pengembangan pariwisata nasional. 
Untuk mencapai tujuan tersebut, Menteri Pariwisata menggunakan istilah Pentaheliks pariwisata yang terdiri dari akademisi (Academics), pelaku bisnis (Business), pemerintah (Government), komunitas atau masyarakat (Community) dan Media yang disingkat dengan ABGCM. Pentaheliks merupakan bagian dari pemangku kepentingan (stakeholder) atau mereka yang terkait dalam mengembangkan pariwisata daerah. Pentaheliks pariwisata tersebut dipandang memiliki pengaruh dan peran dalam meningkatkan jumlah kunjungan wisatawan ke Indonesia. Dengan kata lain, unsur-unsur pentaheliks pariwisata tersebut diharapkan memperkuat sinergi untuk mendorong program pemerintah pusat melalui pengelolaan (manajemen) destinasi wisata.

Namun demikian, peran unsur pentaheliks dalam mempersiapkan sumber daya manusia bidang pariwisata dan mendukung pengembangan pariwisata masih menyisakan pertanyaan. Idealnya, kebijakan pemerintah yang menyangkut sinergitas unsur pentaheliks dalam pengelolaan destinasi wisata khususnya yang berkaitan dengan pengembangan pariwisata daerah harusnya diimplementasikan di tingkat kabupaten/kota. Kenyataannya, unsur pentaheliks nampaknya belum membangun sinergi. Di Provinsi Sulawesi Selatan misalnya, pemerintah daerah telah menjadikan pariwisata sebagai sektor utama pengembangan potensi daerah. Namun, sinergi dari berbagai elemen atau unsur tidak menjadi prioritas utama. Program kepariwisataan cenderung direncanakan dan dijalankan oleh pemerintah serta pelaku usaha pariwisata yang berjalan secara sendiri-sendiri. Sinergitas pentaheliks di daerah nampaknya perlu diidentifikasi khususnya karena keberadaan mereka di tingkat daerah dihalangi oleh keterbatasan informasi dan keterlibatan stakeholder yang belum maksimal.

Pengembangan pariwisata suatu destinasi perlu melibatkan berbagai elemen atau kelompok masyarakat yang ada di suatu destinasi (Cooper dan Hall, 2008:149; Currie, Seaton dan Wesley, 2009: 47; Haugland, et al. 2011: 269). Pengelolaan daya tarik wisata misalnya, tidak dapat dikembangkan jika hanya dikelola oleh satu kelompok masyarakat saja. Dalam hal ini, diperlukan kerjasama yang aktif dan efektif dari berbagai elemen masyarakat mengingat potensi alam dan budaya yang dikelola sebagai aset wisata tergantung kerjasama yang baik dari stakeholder tersebut (Byrd, 2007: 6; Getz dan Timur, 2005:235; Jamal dan Stronza, 2009: 169; Kayat, 2008: 95; Presenza dan Cipollina, 2010: 18).

Kenyataannya, belum terdapat data empiris yang menjelaskan hubungan atau sinergitas yang terbangun antara berbagai kelompok masyarakat dalam konteks pentaheliks pariwisata khususnya di Sulawesi Selatan. Kerjasama antara masyarakat dan pemerintah mungkin saja terbangun secara informal di destinasi wisata, namun keterkaitan kelima elemen pentaheliks tersebut perlu dikaji. Kerjasama yang dimaksud adalah kemampuan setiap unsur pentaheliks pariwisata untuk terlibat dalam mengoptimalkan potensi daerah untuk dikembangkan sebagai aset wisata. Penelitian ini memandang bahwa sinergitas pentaheliks dapat menjadi data empiris mengenai kerjasama yang terbangun antara berbagai unsur pentaheliks. Tujuan penelitian ini adalah 1) mengidentifikasi kondisi faktual sinergi yang terbangun dan faktor-faktor yang menghambat sinergi unsur pentaheliks pariwisata dalam pengelolaan destinasi wisata dan pengembangan pariwisata daerah; 2) menguraikan langkah-langkah yang dapat dilakukan oleh unsur pentaheliks dalam mengembangkan potensi pariwisata daerah. Langkah-langkah ini berkaitan dengan model sinergi pentaheliks pariwisata dalam rangka manajemen destinasi wisata di Provinsi Sulawesi Selatan khususnya di Kota Parepare dan Kab. Bone.

Sinergi dalam kepariwisataan adalah hal penting dalam mengembangkan potensi pariwisata suatu destinasi. Model sinergi menjadi suatu kebutuhan untuk menuntun stakeholder pariwisata dalam membangun destinasi. Sinergi di Sulawesi Selatan perlu dibangun dengan dua alasan utama, pertama pemerintah daerah memerlukan petunjuk bagaimana mengelola potensi daerah tanpa mengabaikan kepentingan dan harapan para stakeholder pariwisata. Kedua, pemerintah daerah perlu melibatkan para stakeholder dalam mengembangkan potensi pariwisata daerah. Rumusan masalah penelitian ini adalah 1) bagaimana kondisi faktual sinergi stakeholder pariwisata di Provinsi Sulawesi Selatan? 2) bagaimana model sinergi unsur- pentaheliks pariwisata dalam mengembangkan potensi pariwisata daerah.

Sinergi atau sinergitas adalah dua istilah yang memiliki makna yang sama, yang berarti kombinasi atau keterpaduan dari berbagai unsur (misalnya unsur pemangku kepentingan) untuk menghasilkan sesuatu yang positif. Dalam pengembangan suatu destinasi, sinergi dapat diartikan sebagai keterpaduan berbagai elemen atau kelompok masyarakat untuk menghasilkan keluaran (output) yang lebih besar. Pemahaman akan tugas dan tanggung jawab masing-masing perlu diwujudkan dengan kerja nyata setiap unsur yang terlibat. Sinergi dapat juga diartikan sebagai upaya mencapai sasaran usaha atau organisasi dalam memenangkan persaingan dengan prinsip kebersamaan (togetherness). Sinergi berkaitan juga dengan istilah kolaborasi atau kemitraan. Dengan demikian, sinergi, kolaborasi ataupun kemitraan dapat menjadi wadah untuk mencapai tujuan suatu organisasi (Jamal dan Getz, 1995).

Pentaheliks adalah kolaborasi lima unsur pemangku kepentingan (stakeholder) pariwisata di destinasi wisata. Stakeholder memegang peranan penting dalam pengembangan suatu destinasi wisata (Bramwell dan Lane, 2000:4; Esu dan Ebitu, 2010: 24). Mereka yang dikategorikan sebagai stakeholder dapat berasal dari elemen masyarakat. Kelompok masyarakat ini dapat berupa mereka yang duduk di pemerintahan, organisasi swasta, industri 
pariwisata, dan masyarakat. Menurut Tuohino dan Konu (2014: 204), stakeholder dapat dikategorikan sebagai anggota masyarakat dari kelompok pemerintahan, kantor atau organisasi pemerintah, pihak swasta dan masyarakat ataupun publik serta lembaga pendidikan yang di dalamnya terdapat kelompok akademisi yang melakukan penelitian (research) untuk kepentingan berbagai kelompok masyarakat.

Teori atau konsep stakeholder memandang atau memfokuskan pentingnya hubungan antara sesama kelompok stakeholder dalam pengelolaan daya tarik wisata atau destinasi wisata (Tuohina dan Konu, 2014: 204). Stakeholder adalah mereka yang memiliki ketertarikan (interest) terhadap pengembangan pariwisata suatu daerah. Stakeholder juga dapat diartikan sebagai mereka yang mendapatkan dampak (effect) dari pelaksanaan suatu kebijakan kepariwisataan dalam suatu lingkup daerah wisata atau destinasi wisata.

Kolaborasi atau kemitraan telah menjadi salah satu strategi dalam melibatkan berbagai kelompok masyarakat dalam kegiatan kepariwisataan. Shaw (2007:190) memberi contoh bagaimana kolaborasi dan kemitraan antara pemerintah, masyarakat (khususnya kelompok minoritas) dan pengusaha bidang pariwisata (business) bekerja bersama membangun pariwisata di Inggris dan Kanada. Menurut Shaw, pelaksanaan festival dan pembuatan perkampungan kelompok masyarakat dilaksanakan melalui keterlibatan berbagai elemen masyarakat. Gambaran kajian teoretis penelitian ini dapat dilihat pada Gambar 1.

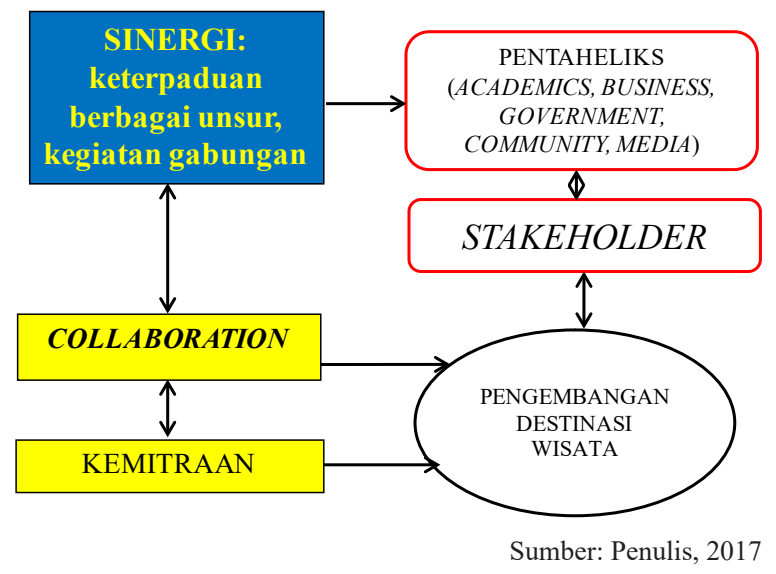

Gambar 1. Gambaran Kajian Teoretis Penelitian METODE

Penelitian ini menerapkan metodologi kualitatif dalam melihat realitas yang ada di lokasi penelitian (Kota Parepare dan Kabupaten Bone). Menurut Flick (2007: ix), penelitian kualitatif bertujuan untuk memahami, menguraikan dan menjelaskan fenomena sosial suatu wilayah geografis. Penelitian ini mengkaji sinergi yang terbangun antar unsur pentaheliks yang ada di destinasi wisata dengan menganalisis informasi yang diperoleh melalui pengumpulan data penelitian. Pengalaman dan pengetahuan yang dimiliki oleh unsur pentaheliks pariwisata menjadi data atau informasi penting dalam manajemen destinasi wisata melalui pendekatan sinergitas.

Uraian yang dihasilkan oleh penelitian kualitatif memungkinkan peneliti mampu menjawab masalah penelitian yang telah dirumuskan. Eksplanasi hasil penelitian merupakan proses ilmiah yang dilakukan peneliti dengan memahami atau menelaah proses dan makna dari data yang diperoleh peneliti (Flick, et al. 2004; Hatch, 2002:151). Belsky (2004:273) berpendapat bahwa dalam penelitian kualitatif, peneliti dapat melihat atau mengamati kegiatan-kegiatan yang berkaitan dengan pariwisata serta makna yang ada dalam proses komunikasi antara peneliti dan subjek peneliti. Sinergitas pentaheliks dapat dipahami secara kritis melalui pendekatan kualitatif.

Penelitian ini memanfaatkan data primer dan sekunder. Data yang diperoleh dari hasil wawancara (interview) dan observasi partisipatori (participant observation) merupakan data primer penelitian ini. Selanjutnya, data sekunder adalah dokumen atau arsip baik yang diterbitkan oleh pemerintah maupun swasta serta publikasi ilmiah yang berkaitan dengan topik penelitian. Informasi yang diperoleh dari website atau internet juga menjadi bahan penting dalam penulisan hasil penelitian.

Penulis telah mendapatkan informasi atau data penelitian melalui wawacara kepada 11 (sebelas) informan yang terdiri dari 6 (enam) orang di kabupaten Bone dan 5 (lima) orang di kota Parepare. Mereka yang terlibat dalam wawancara penelitian ini adalah kalangan atau kelompok masyarakat dari pemerintahan, sektor swasta atau industri pariwisata dan kalangan akademisi di perguruan tingggi. Participant observation ini dilakukan dengan berkunjung ke lokasi penelitian dan berperan sebagai wisatawan. Participant observation ini bertujuan untuk mengidentifikasi dan mengetahui secara langsung kondisi faktual khususnya yang menyangkut senergitas pentaheliks. Penentuan informan dalam wawancara memanfaatkan teknik purposive sampling mengingat informan diharapkan dapat memberikan informasi sesuai konteks penelitian (Altinay dan Paraskevas, 2008:101). Data yang telah diperoleh dianalisis dengan menerapkan prinsip analisis data kualitatif yang terdiri dari fase reduksi data, pengorganisasian dan interpretasi dengan melihat tema-tema (thematic) yang muncul (Arikunto, 2002; Babbie, 2007:375; Ritchie, Spenzer dan William, 2003:220).

\section{HASIL DAN PEMBAHASAN}

\section{Gambaran pariwisata dan kondisi faktual sinergi pentaheliks pariwisata}

Pemerintah Kota Parepare (melalui Kepala Dinas, Bapak Ir. Syukur Razak, M.Si.) berupaya mengembangkan Kota Parepare sebagai destinasi utama di provinsi Sulawesi Selatan. Bapak Iqbal (staf pada bagian pariwisata) mengemukakan bahwa Pemerintah daerah melalui peran 
Dinas Olahraga, Pemuda dan Pariwisata melaksanakan berbagai kegiatan atau event yang berkaitan dengan olahraga, kepemudaan dan kepariwisataan. Berbagai event dilaksanakan untuk mencapai tujuan pemerintah tersebut. Secara khusus, pemerintah merencanakan dan menjalankan event atau festival kedaerahan yakni festival Mallipa yang pelaksanaannya sekitar Maret. Festival Lovely Habibie-Ainun menjadi ikon utama daerah ini dengan menjadikan ikon cinta sejati Habibie-Ainun sebagai tagline utama daerah.

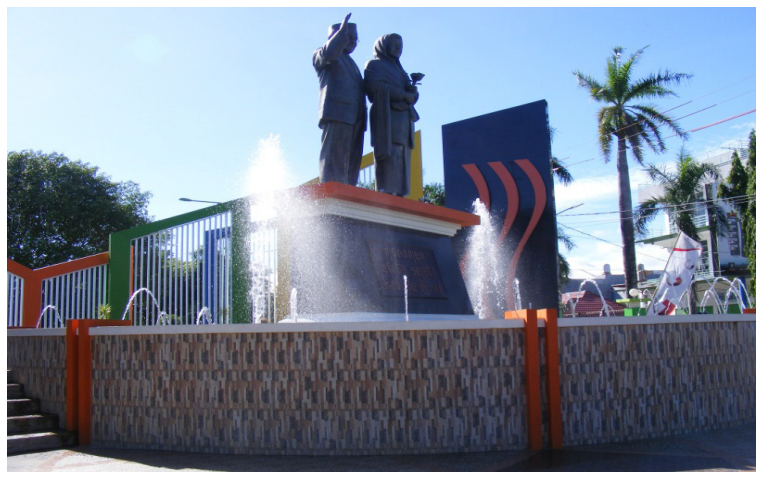

Sumber: Penulis, 2017

\section{Gambar 2. Patung Habibie-Ainun di Kota Parepare}

Penyelenggaraan festival atau pemilihan duta pariwisata menjadi aktifitas utama daerah ini yang dilaksanakan setiap tahun. Periode pelaksanaan kegiatan ini adalah antara pada April hingga Mei setiap tahun. Pemilihan duta pariwisata ini menjadi salah satu event utama mengingat masyarakat secara langsung akan terlibat, baik sebagai peserta maupun sebagai pelaksana kegiatan. Destinasi Parepare telah memiliki dan mengelola daya tarik wisata, baik yang dikelola langsung oleh pemerintah daerah maupun oleh masyarakat setempat. Kebun Raya Jompie adalah contoh daya tarik wisata alam (juga merupakan buatan) yang dikelola secara bersama oleh pemerintah pusat dan Dinas Pariwisata di tingkat daerah. oleh pemerintah daerah.

Alam kota Parepare juga menawarkan daya tarik wisata alam lainnya, misalnya pantai Mattirotasi dan pantai Lumpue yang berlokasi tidak jauh dari kota Parepare. Bagi wisatawan yang mengharapkan aktifitas berenang di pantai, maka pantai Lumpue menjadi pilihan. Pantai ini banyak dikunjungi oleh masyarakat dan wisatawan yang ingin memanfaatkan alam pantai untuk berenang. Pengelolaan pantai ini umumnya masih dikelola masyarakat dengan peran pemerintah yang masih terbatas. Masyarakat yang tinggal di sekitar pantai Lumpue memanfaatkan kunjungan masyarakat dan wisatawan untuk mencari keuntungan ekonomis, misalnya berjualan, menyewakan gazebo, memungut parkir dari kendaraan pengunjung serta menjual makanan dan minuman. Bagi masyarakat setempat, mereka memiliki kewenangan untuk mengelola pantai tersebut karena mereka telah mendiami wilayah tersebut.

Kabupaten Bone sebagai daerah otonom dikenal sebagai wilayah yang juga sangat strategis, lokasi yang dibatasi oleh kabupaten Wajo di bagian utara, kabupaten Maros di bagian barat, kabupaten Sinjai di bagian selatan dan teluk Bone di bagian timur. Lokasi strategis kabupaten Bone dapat dilihat dari posisinya sebagai lokasi perdagangan barang dan jasa yang memungkinkan para pedagang di wilayah Indonesia dan Sulawesi secara khusus bertemu dan melakukan transaksi perdagangan. Ibukota Kabupaten Bone adalah Watampone, pusat aktifitas masyarakat baik dari segi perdagangan maupun dari segi layanan jasa.

Kabupaten Bone dikenal dengan budaya atau adat istiadat Bugis yang masih dipertahankan. Jika pengunjung atau wisatawan berkunjung ke kabupaten Bone, maka pengunjung akan disuguhkan kalimat penyambutan dengan “Bone Beradat", suatu simbolyang mengisyaratkan bahwa Bone menjadi eksis karena kebudayaan yang masih dilestarikan. Pemerintah Kabupaten Bone melalui peran dan kedudukan Dinas Pariwisata ber-upaya mengoptimalkan atau mengembangkan sektor pariwisata sebagai salah satu sektor unggulan pemerintah daerah. Pemerintah daerah berupaya mengoptimalkan pengembangan tiga daya tarik wisata utama daerah, yakni daya tarik wisata Tanjung Pallete dan daya tarik wisata Lanca dan Gua Mampu.

Tanjung Pallette menjadi semakin menarik untuk dikunjungi oleh wisatawan karena pemerintah bersama masyarakat membenahi eksistensi daya tarik wisata tersebut. Selain menawarkan daya tarik wisata alam Tanjung Pallette dengan pemandangan yang indah, pengunjung juga dapat merasakan aktifitas budaya berupa pembelajaran Bahasa Inggris yang dirangkaikan dengan pembelajaran sejarah dan budaya Bone. Selain itu, Goa Mampu menjadi pilihan pengunjung jika ingin merasakan suasana eksplorasi alam dengan nuansa cerita mitos mengenai Goa Mampu tersebut. Ketika melakukan kunjungan, penulis mendapat penjelasan mengenai bebatuan yang memiliki bentuk dan memberikan kisah yang didasarkan oleh pemandu setempat.

Salah satu kelompok stakeholder yang ada di kabupaten Bone adalah kalangan atau kelompok media di mana penduduk memanfaatkannya sebagai salah satu sektor untuk mendapatkan manfaat ekonomis. Media harian Tribun Bone dan Radar Bone adalah contoh media yang saat ini memberikan peluang ke masyarakatnya untuk mengelola dan memberikan informasi ke publik dalam bentuk media cetak. Radio juga menjadi media utama daerah dengan berbagai kelompok radio khususnya cabang dari radio Republik Indonesia (RRI). Media televisi lokal juga telah berjalan dengan ciri khas kedaerahan selain media televisi nasional sebagai bagian tak terpisahkan dari pemberian informasi ke khalayak publik.

Industri pariwisata telah mulai berkembang di Kabupaten Bone. Industri akomodasi misalnya, nampaknya mulai berkembang dengan semakin banyaknya jumlah tamu yang mengisi akomodasi yang ada di kabupaten Bone. Usaha cafe atau restoran adalah industri atau usaha pariwisata yang banyak mengalami peningkatan dalam 
hal jumlah. Ketika melakukan eksplorasi, penulis melihat jumlah kafe di pinggiran jalan di kota Watampone. Hal ini menjadi angin segar bagi destinasi Bone bahwa kehadiran cafe tersebut memberikan kesempatan kepada masyarakatnya untuk bekerja di sektor jasa, salah satunya melalui usaha makan dan minum. Resto cafe yang berlokasi di Jalan Jenderal Sudirman adalah contoh cafe yang banyak dikunjungi oleh pengunjung.

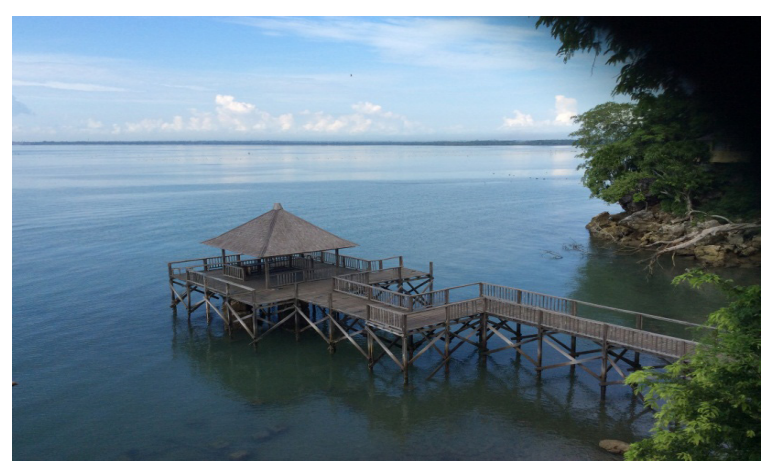

Sumber: Penulis, 2017

\section{Gambar 3. Tanjung Pallette di Kabupaten Bone}

Kota Parepare dan Kabupaten Bone Provinsi Sulawesi Selatan telah memiliki kelima unsur pentaheliks pariwisata daerah yang terdiri dari akademisi (academics), pengusaha (business), pemerintah daerah melalui Dinas Pariwisata Daerah (government), masyarakat (community) dan media. Kelima unsur tersebut pada dasarnya memiliki peran dalam mengembangkan pariwisata meskipun dalam realita, belum terdapat data secara kuantitatif persentasi keterlibatan unsur pentaheliks dalam mengembangkan potensi pariwisata daerah. Kelima unsur pentaheliks tersebut telah terlibat dalam pengembangan potensi pariwisata daerah meskipun tingkat keterlibatan mereka bervariasi tergantung pada perannya sebagai stakeholder pariwisata.

Peran akademisi di daerah sangat tergantung pada bagaimana pemerintah daerah memanfaatkan eksistensi mereka sebagai pihak yang secara akademis memberikan solusi pengelolaan destinasi wisata. Di Kota Parepare misalnya, akademisi bidang pariwisata dapat dilihat dari kedudukan dan peran pengajar atau guru-guru Sekolah Menengah Kejuruan (SMK) pariwisata (misalnya Ibu Salasiah dan Bapak Arqam, pengajar di STAIN Parepare). Sesungguhnya, konektifitas antara akademisi bidang pariwisata pada sekolah menengah dengan pemerintah daerah masih perlu ditingkatkan. Hal ini penting dilakukan mengingat pemerintah daerah memerlukan pembantuan dari para akademisi di tingkat daerah dalam hal rekomendasi program pengembangan potensi pariwisata daerah. Demikian pula eksistensi perguruan tinggi melalui para akademisinya di Kota Parepare nampaknya masih perlu ditingkatkan mengingat belum terdapat studi kajian pariwisata yang secara khusus membidangi pariwisata atau kepariwisataan.

Pemerintah daerah Kota Parepare pada dasarnya telah memanfaatkan eksistensi akademisi di Sulawesi
Selatan untuk mengelola dan mengembangkan potensi pariwisata daerah. Kemitraan dan kerjasama yang dibangun antara Dinas Pariwisata dengan institusi pendidikan tinggi bidang pariwisata adalah bukti bahwa para akademisi telah menjalankan langkah pembimbingan kepariwisataan ke masyarakat di Kota Parepare. Selain itu, kegiatan sosialisasi kepariwisataan serta aktifitas akademik lain yang dilaksanakan institusi pendidikan tinggi yang berasal dari Kota Makassar menjadi salah satu indikasi adanya peran dan fungsi akademisi dalam mengembangkan potensi daerah baik yang berkaitan dengan kepariwisataan maupun bidang lain yang diperuntukkan untuk pengembangan potensi kewilayahan demi kepentingan masyarakat.

Di Kabupaten Bone, eksistensi akademisi di tingkat daerah telah mulai dilirik pemerintah daerah. Pengelolaan Tanjung Pallette sebagai kawasan wisata misalnya, telah melibatkan kelompok atau individu dari perguruan tinggi daerah untuk terlibat dalam mengelola dan memaksimalkan program pemerintah daerah melalui aktifitas bahasa dan kepariwisataan. Sinergi antara pemerintah daerah dan akademisi di daerah ini ditunjukkan dengan peran alumni perguruan tinggi dalam menjalankan program yang difasilitasi oleh pemerintah daerah (Dinas Pariwisata) dengan sasaran utama generasi muda Kabupaten Bone dan staf pemerintah daerah yang berperan sebagai pemberi informasi kepariwisataan ke wisatawan.

Langkah pemberian sosialisasi kepariwisataan oleh akademisi dari luar kabupaten Bone adalah indikasi bahwa pemerintah daerah masih mengandalkan akademisi dari luar untuk berkontribusi dalam merekomendasikan strategi pengembangan destinasi wisata. Dengan kata lain, peran pendampingan oleh perguruan tinggi dari luar Kabupaten Bone masih menjadi pilihan pemerintah daerah. Sementara itu, keterbatasan akademisi di tingkat daerah khususnya bidang pariwisata masih terbatas. Namun demikian, Kabupaten Bone memiliki akademisi bidang lain (misalnya kebudayaan) yang memerhatikan hal-hal yang bersifat potensi kebudayaan sehingga memungkinkan pengembangan daerah melalui aspek pariwisata budaya. Kabupaten Bone memiliki sanggarsanggar budaya yang dirintis oleh akademisi yang mencintai kebudayaan daerah.

Kebudayaan menjadi salah satu aset penting di Kabupaten Bone. Karya-karya ilmiah yang ditulis oleh budayawan daerah menungkinkan adanya upaya melestarikan potensi budaya sebagai aset pariwisata budaya. Sebagai contoh, Andi Makmur Makka menulis buku dengan judul 'Rumpa'na Bone" dan Asmat Riyadi yang menulis buku 'Kamus Lengkap Bahasa BugisIndonesia'. Pada umumnya, penelitian-penelitian yang dilakukan oleh banyak peneliti di Kabupaten Bone banyak difokuskan pada kebudayaan dalam berbagai perspektif. Dengan demikian, selain potensi alam yang dimiliki daerah, potensi pariwisata budaya juga sangat berpeluang 
untuk dikelola dan dikembangkan dengan peran dan fungsi akademisi dalam memberikan usulan strategi pengembangan.

Pengusaha (misalnya, Haji Carlos, pengusaha pantai pasir putih, café dan industri kreatif; Ibu Mardiah, pengusaha bidang café/resto, dll) di daerah-daerah di Sulawesi Selatan juga telah memberikan atau melakukan langkah-langkah dalam rangka mengembangkan potensi pariwisata daerah. Kota Parepare menjadi salah satu destinasi yang telah sukses mengembangkan pariwisata dengan peran pengusaha bidang pariwisata. Jika dibandingkan dengan Kota Makassar, Kota Parepare mungkin masih jauh dari segi peran dan fungsi pengusaha untuk terlibat dalam aktifitas pariwisata. Namun demikian, jumlah hotel dan restaurant (termasuk cafe) menjadi salah satu pendorong majunya atau meningkatnya pariwisata di Kota Parepare. Eksistensi hotel di beberapa lokasi di Kota Parepare menjadi kekuatan utama bahwa pengusaha atau pebisnis telah mulai melirik pariwisata sebagai salah satu peluang usaha.

Meskipun pengusaha di daerah telah bekerja mengembangkan usahanya sesuai dengan bidang yang mereka geluti (industri pariwisata), namun tidak sedikit pengusaha yang belum memahami makna sertifikasi usaha pariwisata. Pemerintah daerah melalui Dinas Pariwisata telah bekerja menyampaikan ke industri pariwisata tujuan sertifikasi usaha pariwisata. Namun demikian, jumlah industri pariwisata atau pengusaha bidang pariwisata yang memperhatikan sertifikasi usaha pariwisata cenderung masih sangat kurang. Dalam hal penerimaan karyawan yang kompeten dalam usaha pariwisata misalnya, pengusaha pariwisata cenderung merekrut karyawan tanpa memerhatikan aspek kompetensi karyawan yang akan bekerja di usaha mereka. Dengan demikian, dapat dikatakan bahwa langkah unsur pengusaha dalam mengembangkan potensi pariwisata masih tergantung pada program yang dijalankan oleh Dinas Pariwisata.

Kabupaten Bone juga menjadi destinasi wisata yang melibatkan peran pengusaha dalam memajukan pariwisata daerah. Dibandingkan Kota Parepare, pengusaha bidang pariwisata di Kabupaten Bone lebih kurang dalam hal keterlibatan dalam usaha akomodasi. Usaha akomodasi juga telah ada meskipun jumlahnya tidak sebanyak di Kota Parepare. Namun, eksistensi cafe ataupun restoran yang cenderung meningkat di Kabupaten Bone menunjukkan bahwa peran pengusaha di daerah ini sudah menunjukkan hasil yang memuaskan. Penulis memanfaatkan kunjungan penelitian di Kabupaten Bone dengan menikmati hidangan di sebuah cafe. Deretan cafe ataupun restoran di destinasi ini dapat dilihat oleh wisatawan ataupun mereka yang mengunjungi Kabupaten Bone. Hal ini memungkinkan adanya beberapa pilihan bagi wisatawan untuk menikmati suasana rileks atau santai ketika mengunjungi daya tarik wisata ataupun usaha pariwisata di Kabupaten Bone.

Pemilihan karyawan di Kabupaten Bone tidak terlalu berbeda dengan kondisi faktual di Kota Parepare. Pemilihan karyawan yang tidak memerhatikan prinsip kompetensi sebagaimana yang diamanahkan oleh UndangUndang Nomor 10 tahun 2009 tentang Kepariwisataan masih menjadi realita di Kabupaten Bone. Ini berarti bahwa langkah pengusaha lokal dalam mengembangkan pelayanan wisatawan dalam bentuk sistem karyawan yang memiliki kualifikasi kompetensi belum menjadi prioritas utama pengusaha. Kecenderungan di daerah menunjukkan bahwa karyawan yang bekerja di industri pariwisata belum memerhatikan sistem kompetensi karyawan. Hal ini tentunya akan berpengaruh terhadap kualitas pemberian layanan mengingat sistem kompetensi memiliki standar kualifikasi pelayanan sesuai dengan tugas pokok setiap pemberi layanan di bidang industri pariwisata.

Langkah pengusaha dalam mengembangkan potensi pariwisata daerah di dua destinasi di Sulawesi Selatan (Kota Parepare dan Kabupaten Bone) ditunjukkan dalam tiga tahap atau usaha. Pertama, industri pariwisata atau pengusaha akan sangat tergantung pada instruksi atau arahan pemerintah. Hal ini berarti bahwa langkah pengusaha dalam memajukan pariwisata daerah akan sangat tergantung pada bagaimana pemerintah mengupayakan sosialisasi peraturan yang berkaitan dengan kepariwisataan serta hal-hal yang berkaitan dengan sistem kepariwisataan. Oleh karena itu, dibutuhkan upaya yang maksimal oleh pemerintah dalam memberikan instruksi kepada para pengusaha untuk memerhatikan peraturanperaturan serta sosialisasi kepada pihak pengusaha.

Kedua, industri pariwisata telah berupaya melakukan langkah pengelolaan destinasi wisata melalui usaha yang mereka kembangkan, baik berupa akomodasi, layanan makan dan minum maupun usaha lainnya. Hal ini dapat disimpulkan bahwa mereka (pengusaha) telah menjalankan usaha pariwisata sesuai dengan kapasitas kemampuan mereka. Ketiga, pemahaman tentang sistem pelayanan pariwisata yang maksimal masih menjadi kendala bagi kebanyakan pengusaha di tingkat daerah. Salah satu penyebabnya adalah karena keterbatasan informasi mengenai bagaimana seharusnya mereka mengembangkan usaha melalui prinsip pelayanan yang maksimal. Kekuatan modal atau investasi juga menjadi persoalan bagi pengusaha daerah. Karena itu, langkah para pengusaha untuk membuka usaha bidang pariwisata perlu dukungan dengan kemudahan membuka dan mengembangkan usaha bidang pariwisata dan hospitaliti, misalnya akomodasi atau hotel, restoran, usaha perjalanan, katering, dll.

Pemerintah (melalui Dinas Pariwisata daerah) di dua destinasi wisata telah menjalankan peran sebagai stakeholder utama pengelolaan destinasi wisata. Pemerintah daerah telah melaksanakan langkah-langkah pengembangan pariwisata dengan merencanakan dan menjalankan program yang berkaitan dengan pariwisata. Kegiatan festival adalah salah satu program yang dijalankan sebagai upaya untuk menarik wisatawan berkunjung ke destinasi mereka. Masyarakat sebagai salah satu unsur pentaheliks pariwisata menjadi salah satu bagian penting 
dalam mengembangkan potensi pariwisata daerah. Masyarakat (community) dalam konteks penelitian ini dapat dilihat khususnya mereka yang tinggal di sekitar daya tarik wisata.

Dalam mengelola destinasi wisata daerah, terdapat beberapa faktor, tantangan atau kendala yang dihadapi pemerintah daerah dan unsur-unsur pentaheliks pariwisata. Faktor-faktor tersebut sesungguhnya terjadi karena berbagai hal, baik yang berhubungan dengan sistem yang diterapkan di suatu daerah ataupun faktor yang terjadi karena dari unsur pentaheliks itu sendiri. Kota Parepare dan Kabupaten Bone tidak terlepas dari faktor atau tantangan yang akan diuraikan sebagai berikut.

Otonomi daerah telah diterapkan di Indonesia sebagai sebuah sistem yang memberikan kewenangan kepada pemerintah daerah untuk mengatur daerahnya dengan prinsip-prinsip memerhatikan kepentingan masyarakat serta dengan melihat potensi yang ada. Otonomi daerah juga mengatur pemerintah daerah untuk menyelenggarakan pengembangan dan pengelolaan aset pariwisata sesuai dengan potensi kedaerahan masing-masing. Hal ini dapat dilihat dari hak pemerintah daerah untuk mengatur nama atau nomenklatur Dinas Pariwisata yang mengaitkan dengan dinas lain, misalnya pariwisata dan kebudayaan atau pariwisata dan pemuda, dll. Hal ini diartikan bahwa pemerintah daerah telah menggunakan hal atau peluang mengatur daerah sesuai dengan kepentingan daerah masing-masing.

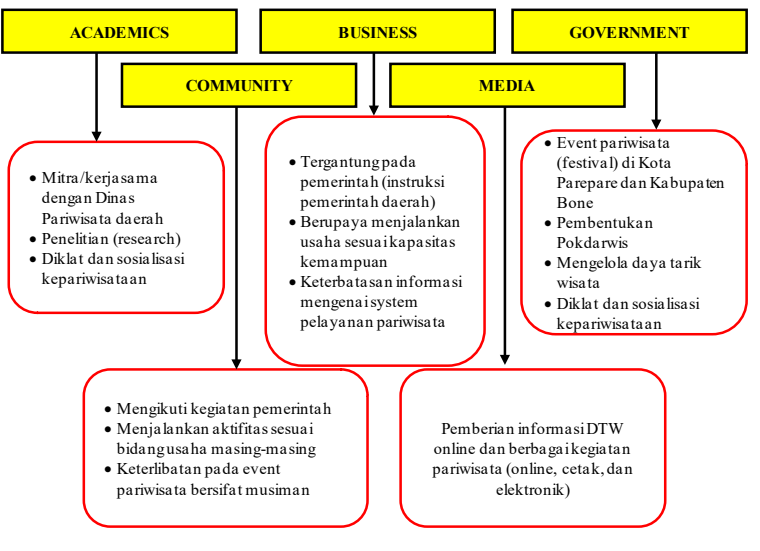

Sumber: Penulis, 2017

Gambar 4. Kondisi Faktual Sinergi Pentaheliks Pariwisata Di Kota Parepare dan Kabupaten Bone

\section{Model Sinergi Pentaheliks Pariwisata}

Di Kota Parepare, pemerintah daerah telah menjalankan fungsi dan peran pengembangan pariwisata melalui peran Dinas Pariwisata setempat. Otonomi daerah telah memungkinkan daerah Kota Parepare untuk mengatur strategi pengembangan pariwisata. Penerapan otonomi daerah sesungguhnya memberikan kesempatan yang baik kepada daerah untuk berkembang dan kreatif mengelola sumber daya alam termasuk bidang pariwisata. Kota Parepare termasuk daerah yang mencoba menerapkan langkah-langkah kreatifmelalui program atau ikon Habibie-Ainun. Dengan otonomi daerah ini, daerah akan berupaya menciptakan peluang dan inovasi baru yang berkaitan dengan program kerja bidang pariwisata.

Akan tetapi, otonomi daerah dapat menjadi tantangan atau hambatan dalam membangun sinergi dari berbagai unsur pentaheliks. Hambatan tersebut khususnya terjadi ketika daerah kurang memerhatikan sinergi dengan unsur pemerintahan pada tingkat regional dan nasional. Hal ini dapat terjadi termasuk di Kota Parepare jika pemerintah daerah kurang memiliki koordinasi ataupun sinergi dengan pemerintah provinsi (melalui Dinas pariwisata tingkat provinsi) dan pemerintah pusat (Kementerian Pariwisata). Meskipun komitmen untuk melakukan sinergi antara berbagai unsur pentaheliks pariwisata menjadi harapan pemerintah daerah, namun otonomi daerah dapat menjadi alasan lemahnya sinergi yang akan dibangun oleh pemerintah daerah. Gambaran sinergi yang terbangun dan bagaimana pentaheliks pariwisata terlibat dalam aktifitas pariwisata dapat dilihat pada Gambar 4.

Otonomi daerah juga menuntun pemerintah Kabupaten Bone dengan prinsip bahwa pemerintah daerah berhak untuk mengelola aset pariwisata sesuai dengan kebijakan daerah. Sebagaimana halnya dengan di Kota Parepare, Kabupaten Bone, kewenangan pemerintah daerah dapat dimaknai (disalah artikan) sebagai hak untuk mengelola sesuai dengan kebijakan daerah tanpa melihat pentingnya sinergi dengan unsur pentaheliks lainnya. Kebijakan dalam menentukan mitra atau kerjasama misalnya, menjadi hak Dinas pariwisata sehingga tidak ada panduan atau rambu yang digunakan untuk menjalin mitra kerjasama. Jika mitra kerjasama dibangun tanpa memperhatikan prinsip kepentingan sinergi pentaheliks pariwisata, maka dapat dikatakan bahwa otonomi daerah cenderung diimplementasikan secara tidak tepat. Kewenangan daerah adalah untuk membantu pemerintah daerah mengembangkan aset pariwisata dengan harapan sinergi antar unsur pentaheliks semakin dibangun di bawah peran dan fungsi pemerintah daerah setempat. Koordinasi yang baik dengan pemerintah pusat dan provinsi menjadi keharusan agar otonomi daerah tidak menjadi pemanfaatan kewenangan semata, tetapi sebagai alat atau media untuk mendorong daerah menciptakan langkah-langkah kreatif menjalankan program yang lebih kreatif di bidang pariwisata oleh Dinas Pariwisata.

Pengelolaan destinasi wisata masih terkendala dengan kemampuan staf dalam membuat atau merencanakan program-program pariwisata yang kreatif dan inovatif. Salah satu penyebabnya adalah karena terdapat staf di Dinas Pariwisata yang tidak atau bukan dari latar belakang pariwisata. Idealnya, staf yang ditempatkan memiliki keilmuan atau berasal dari latar belakang pariwisata untuk menunjang pengelolaan destinasi wisata. Namun, daerah nampaknya membutuhkan staf yang memiliki keilmuan dan pengalaman di bidang pariwisata untuk mendorong penciptaan program kerja yang inovatif. Rendahnya kesadaran masyarakat akan makna dan pentingnya pariwisata juga perlu diantisipasi dengan 
memberikan pelatihan atau sosialisasi kepariwisataan. Peningkatan kesadaran masyarakat juga menjadi salah satu prasyarat untuk membangun destinasi wisata. Kesadaran juga menjadi kendala atau tantangan dalam pengelolaan destinasi. Karena itu, dibutuhkan sinergi yang berkelanjutan (sustainable) dari berbagai kelompok pentaheliks untuk membantu pemerintah mewujudkan pengembangan destinasi wisata.

Tantangan, hambatan ataupun faktor-faktor yang memengaruhi pengelolaan destinasi wisata serta daya tarik wisata perlu ditindaklanjuti dengan model ataupun strategi pengelolaan aset pariwisata maupun program pengembangan pariwisata. Motivasi wisatawan untuk mengunjungi suatu destinasi ditindaklanjuti dengan pengelolaan daya tarik wisata yang professional (Indira, Ismanto dan Santoso, 2013). Pariwisata diperuntukkan untuk kepentingan masyarakat sehingga strategi yang diterapkan selayaknya memerhatikan kepentingan masyarakat. Penelitian ini merekomendasikan beberapa langkah strategis atau model membangun sinergi antara unsur Pentaheliks yang ada di daerah yang diuraikan sebagai berikut:

Strategi pertama yang dapat menjadi pilihan dalam mengelola destinasi wisata adalah pentingnya menerapkan atau mengimplementasikan tata kelola destinasi atau destination management organisation (DMO). Tata kelola destinasi ini merupakan konsep baru yang telah diadopsi beberapa negara di dunia dalam mengelola dan mengembangkan pariwisata daerah. Di Indonesia, tata kelola destinasi menjadi perhatian dari berbagai kelompok masyarakat khususnya mereka yang aktif di dunia pariwisata (misalnya Swiss Contact). Tata kelola destinasi menjadi salah satu pilihan karena implementasinya menghendaki adanya kerjasama, kolaborasi ataupun kemitraan yang dibangun oleh berbagai pemangku kepentingan (stakeholder) di suatu destinasi wisata (Park, Lehto dan Morrison, 2008; 396; Junaid, 2015:35; Bornhorst, Ritchie and Sheehan, 2010:573).

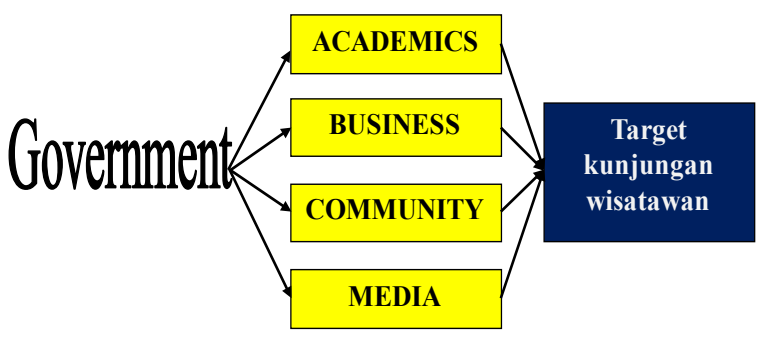

Gambar 5. Model implementasi DMO dalam sinergi unsur pentaheliks pariwisata

Tata kelola destinasi (DMO) dapat diterapkan dalam konteks yang berbeda. Salah satu prinsip DMO adalah adanya satu kelompok ataupun individu yang bertanggung jawab atau diberikan amanah untuk melakukan peran koordinasi dan kerjasama dengan berbagai kelompok atau elemen masyarakat yang tergabung dalam unsur tata kelola destinasi (Morrison, 2012:5). Secara khusus, penelitian ini merekomendasikan pengelolaan pariwisata daerah berdasarkan konsep DMO dengan pendekatan pemerintah sebagai aktor utama baik dalam hal peran kepemimpinan (leadership) maupun dalam hal pemasaran (marketing) (Junaid, 2015:30). Leadership dan marketing adalah bagian dari tugas pemerintah yang harus dijalankan jika konsep DMO akan diterapkan berdasarkan pendekatan tersebut.

Kota Parepare dan Kabupaten Bone dapat menerapkan pendekatan tersebut dengan menjadikan Dinas Pariwisata tingkat kabupaten dan kota sebagai pemimpin (leader) dalam hal koordinasi dengan unsur pentaheliks lainnya. Dalam implementasinya, Dinas pariwisata daerah selayaknya melakukan indentifikasi awal pihak-pihak yang terlibat ataupun mereka yang merupakan representatif dari kelompok akademisi (academics), pengusaha (business), masyarakat (community), dan media. Identifikasi awal ini akan membantu pemerintah dalam memasukkan atau melibatkan mereka dalam satu payung organisasi atau tata kelola destinasi (DMO) tingkat kabupaten dan kota. Selanjutnya, mereka akan diundang untuk duduk sebagai anggota ataupun perwakilan dari kelompok pentaheliks yang ada di daerah. Sinergi akan mulai dijalankan ketika proses identifikasi telah dilaksanakan. Selanjutnya, dibutuhkan peran setiap unsur pentaheliks khususnya pemerintah dalam membangun sinergi serta mendukung program kerja setiap bidang Dinas Pariwisata.

Model kedua yang dapat menjadi alternatif membangun sinergi antara berbagai unsur pentaheliks di Kota Parepare dan Kabupaten Bone adalah pentingnya memaksimalkan kawasan wisata yang telah dibuat atau dirintis untuk menjadi kawasan wisata percontohan. Di Kabupaten Bone, terdapat satu kawasan wisata yakni Tanjung Pallette. Keberadaan Tanjung Pallette pada tiga tahun terakhir menjadi kurang diperhatikan mengingat adanya daya tarik wisata lain yang lebih menonjol dan menjadi pilihan masyarakat. Daya tarik wisata berupa pemandian alam buatan menjadi pemikat wisatawan atau pengunjung yang datang ke Tanjung Pallette, namun kawasan wisata yang dikelola oleh pemerintah setempat cenderung kurang mendapat kunjungan.

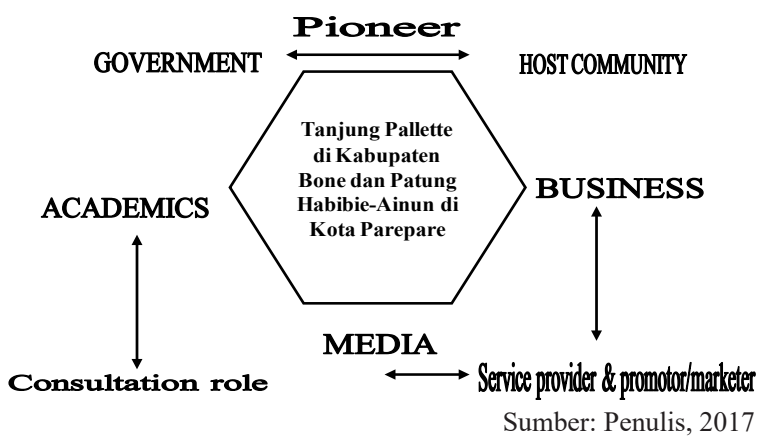

Gambar 6. Model Optimalisasi Kawasan dan Ikon Wisata Dalam Manajemen Destinasi Wisata

Tanjung Pallette saat ini telah dilirik oleh pemerintah setempat (melalui Dinas Pariwisata) dan mulai mendapat perhatian baik dari masyarakat setempat maupun dari 
wisatawan. Penulis melakukan eksplorasi Tanjung Pallette dan mendapatkan kesan positif dengan aktifitas masyarakat di dalam kawasan wisata tersebut berupa pembelajaran Bahasa Inggris. Kegiatan ini telah mendapat dukungan dari pemerintah setempat dan masyarakat yang memanfaatkan rumah mereka sebagai tempat penginapan (homestay) maupun sebagai tempat pengunjung memanfaatkan waktu istirahat sambil menikmati alam Tanjung Pallette.

Tanjung Pallette dapat menjadi contoh pengelolaan kawasanwisataalamyangberbasismasyarakat(community based tourism). Contoh dalam konteks penelitian ini adalah model atau acuan bagi wilayah atau destinasi lain baik yang ada di Sulawesi Selatan maupun di Indonesia untuk mengadopsi upaya yang dilakukan masyarakat di sekitar daya tarik wisata Kabupaten Bone. Rumah-rumah masyarakat yang ada di sekitar Tanjung Pallette disulap menjadi rumah tinggal (penginapan) yang representatif untuk dimanfaatkan pengunjung. Rumah-rumah mereka diberi penanda berupa nama-nama raja atau istilah-istilah bugis dimana pengunjung akan belajar atau memperoleh informasi yang berkaitan dengan kebudayaan Bone.

Kegiatan tersebut didukung oleh pemerintah setempat dan dijalankan oleh alumni suatu perguruan tinggi di Kabupaten Bone. Dari hasil wawancara penulis, kegiatan tersebut baru dimulai di tahun 2017 dengan dukungan dari pemerintah setempat. Pegawai atau staf Dinas Pariwisata juga diharapkan ikut pada kegiatan pembelajaran Bahasa Inggris di lokasi wisata tersebut dengan harapan memberikan keterampilan dan kemampuan berbahasa asing bagi staf Dinas Pariwisata daerah. Dukungan dan komitmen pemerintah menjadi kekuatan pada program ini selain keikutsertaan dan kesediaan masyarakat memanfaatkan kawasan tersebut dan rumah mereka sebagai pondok yang representatif.

Di Kota Parepare, pemerintah daerah telah mengupayakan strategi untuk meningkatkan jumlah kunjungan wisatawan ke destinasi Parepare. Upaya yang paling signifikan adalah dibangunnya patung Habibie-Ainun di tengah-tengah kota Parepare atau di sudut lapangan Andi Makkasau. Patung ini telah menjadi perhatian banyak wisatawan ketika berkunjung ke kota Parepare. Berdasarkan observasi penulis, wisatawan banyak memanfaatkan atau menghabiskan waktu mereka untuk mengambil gambar dengan latar belakang patung Parepare. Para wisatawan atau pengunjung umumnya menjadikan patung Habibie-Ainun sebagai titik point pengambilan gambar bersama keluarga mereka. Aktifitas pengambilan gambar ini dapat dikatakan berjalan sepanjang waktu dari pagi hingga malam hari. Pada malam hari, pengambilan gambar nampaknya sangat baik mengingat cahaya yang dipancarkan memungkinkan wisatawan melihat keunikan dan kekhasan patung dari sudut pandang cahaya yang variatif.

Sinergi pentaheliks pariwisata dapat dilihat dari peran pemerintah dan masyarakat di destinasi khususnya sekitar daya tarik wisata sebagai pencetus (pioneer) dalam membuat program percontohan atau kawasan wisata. Peran akademisi adalah memberikan bantuan pembimbingan atau konsultasi kepada pemerintah dan masyarakat sesuai kebutuhan pengembangan destinasi wisata. Tugas utama pengusaha pariwisata dan masyarakat adalah memberikan pelayanan yang maksimal kepada consumer (customer) serta memberikan dan menyebarkan informasi yang bermanfaat untuk masyarakat dan wisatawan. Dengan kata lain, peran sebagai service provider dan promotor/ marketir menjadi suatu kekuatan yang dijalankan oleh pengusaha dan media. Gambaran sinergi tersebut dapat dilihat pada Gambar 6.

Pemilihan ikon Habibie-Ainun menjadi strategi menarik dari pemerintah daerah kota Parepare. Strategi ini dipilih berdasarkan beberapa pertimbangan, misalnya, karena Bapak Habibie adalah mantan presiden Republik Indonesia dengan kota Parepare sebagai kota kelahiran. Pemilihan ikon cinta sejati Habibie-Ainun menjadi daya tarik bagi kebanyakan wisatawan atau pengunjung yang datang ke kota Parepare. Cinta sejati Habibie-Ainun dijadikan sebagai ikon dengan maksud untuk memastikan bahwa Parepare memiliki cerita yang unik dan menarik yang diambil dari kisah mantan presiden Republik Indonesia (Junaid dan Hanafi, 2016: 134). Untuk semakin mendukung program pemerintah bidang pariwisata melalui ikon cinta sejati Habibie-Ainun, pemerintah daerah menyelenggarakan event festival Habibie-Ainun atau festival cinta sejati Habibie-Ainun.

Strategi go digital menjadi salah satu alternatif dalam mengelola aset wisata daerah dalam meningkatkan tingkat kunjungan ke destinasi wisata. Go digital telah menjadi program pemerintah pusat yang diprakarsai oleh Menteri Pariwisata Republik Indonesia, Dr. Arief Yahya. Strategi ini diartikan sebagai suatu langkah memudahkan pemberian dan pelayanan informasi kepada wisatawan dengan memanfaatkan teknologi modern yang bersifat digital. Go digital dijalankan dengan penggunaan perangkat teknologi yang variatif yang memungkinkan wisatawan memperoleh informasi dengan mudah sehingga akan berpengaruh pula pada kemudahan wisatawan dalam melakukan perjalanan. Go digital ini juga memberikan kemudahan bagi pengelola atau pemberi layanan pariwisata melalui teknologi untuk kemudahan wisatawan.

Dinas Pariwisata kota Parepare telah berupaya memanfaatkan teknologi dalam mempromosikan daya tarik wisata ataupun destinasi Parepare ke dunia internasional. Hal yang sama pula telah dilakukan oleh pemerintah kabupaten Bone dengan memanfaatkan internet (website) yang memungkinkan calon wisatawan mengakses informasi yang dibutuhkan. Namun demikian, penerapkan perangkat lunak (software) yang berkaitan dengan sistem informasi pariwisata nampaknya masih kurang menjadi perhatian kedua daerah ini. Di provinsi Sulawesi Selatan, Dinas Pariwisata Kota Makassar dan Dinas Pariwisata Provinsi Sulawesi Selatan adalah pihak atau pengelola daerah yang telah memiliki software 
yang berfungsi sebagai pemberi layanan informasi kepariwisataan. Hal ini dapat ditiru oleh pemerintah Kota Parepare dan Kabupaten Bone dalam memanfaatkan teknologi untuk strategi pengembangan pariwisata daerah. Pattanaro (2014:222) berpandangan bahwa kesuksesan pemasaran destinasi wisata tidak terlepas dari bagaimana suatu stakeholder menjalankan kolaborasi atau bekerja secara bersama mencapai tujuan yang diharapkan.

Strategi pengembangan pariwisata berbasis go digital dapat dijalankan oleh kelima unsur pentaheliks pariwisata di daerah. Pertama, akademisi (baik mereka dari kalangan atau ahli teknologi maupun keahlian lain) dapat berperan dalam membuat suatu software atau perangkat lunak sistem informasi kepariwisataan yang dapat dimanfaatkan oleh pemerintah setempat. Akademisi adalah kelompok masyarakat yang mengkaji berbagai isu baik yang berkaitan dengan teknologi, informasi maupun kepariwisataan. Pemerintah daerah Kota Parepare dan Kabupaten Bone dapat bekerja bersama akademisi dalam menjalankan suatu proyek teknologi informasi yang berkaitan dengan kepariwisataan. Dengan kata lain, peran akademisi adalah mengusulkan suatu program yang merupakan hasil kajian mereka yang bertujuan untuk memberikan pelayanan informasi kepariwisataan kepada publik khususnya wisatawan yang dijalankan oleh pemerintah sebagai stakeholder utama pengembangan pariwisata daerah.

Peran akademisi dalam konteks penelitian ini dapat dibagi ke dalam dua bagian yakni menciptakan atau membuat program atau software secara online dan menciptakan atau membuat software offline. Program go digital secara online yakni sistem yang dijalankan dengan memanfaatkan sistem teknologi berbasis internet atau website. Menurut Priyambodo (2013:B19), pemberian layanan bidang pariwisata selayaknya memanfaatkan teknologi web-service, sistem yang memudahkan pengguna atau wisatawan melaksanakan aktifitas pariwisata di destinasi wisata. Sistem digital dan connectivity dapat memberikan peluang peningkatan perekonomian baik yang berdampak pada masyarakat maupun kepada suatu wilayah atau destinasi (Arman, et al., 2016:98). Selanjutnya, sistem secara offline yakni pemanfaatan teknologi tanpa memanfaatkan sistem teknologi berbasis internet. Dalam hal ini, pembuatan sistem touch screen dapat menjadi contoh alternatif media offline dimana wisatawan ataupun publik dapat memanfaatkan sistem teknologi tersebut. Sebagai contoh, sistem pelayanan transportasi yang bersifat offline dimanfaatkan oleh wisatawan atau masyarakat di bandara Sultan Hasanuddin dengan fitur touch screen dan pilihan jenis moda transportasi taksi yang dipilih.

Pengusaha (business) juga dapat membuat atau menciptakan perangkat lunak (software) yang bersifat online dan offline. Pengusaha sebagai pihak swasta adalah mereka yang bekerja untuk kepentingan profit atau keuntungan. Karena sifat kegiatan mereka adalah profit, maka pemerintah di suatu destinasi seharusnya mendorong para pengusaha untuk berfikir inovatif dan kreatif untuk menciptakan sistem pelayanan informasi wisatawan berbasis online. Sistem pelayanan informasi akomodasi yang disediakan traveloka misalnya, adalah contoh perangkat lunak (software) yang bersifat kreatif. Para pengusaha juga perlu menciptakan berbagai bentuk pelayanan informasi pariwisata dalam berbagai bentuk yang bersifat online. Suatu perusahaan ataupun pengusaha bidang pariwisata dapat menciptakan sistem teknologi yang bersifat offline yang diletakkan di kantor dimana wisatawan ataupun pelanggan (customer) dapat memanfaatkan sistem tersebut untuk kemudahan pelayanan mereka. Selain itu, sistem teknologi yang bersifat online dapat pula ditempatkan di daya tarik wisata dimana wisatawan akan langsung memanfaatkan informasi mengenai daya tarik wisata tersebut.

Pemerintah harus berperan aktif untuk mendorong berbagai kelompok masyarakat untuk menciptakan suatu sistem layanan informasi kepariwisataan berbasis online dan offline. Berbagai upaya dapat dilakukan oleh pemerintah untuk menciptakan perangkat lunak yang berbasis teknologi tersebut, misalnya pemerintah mencanangkan program atau lomba kreatifitas teknologi atau software di bidang pariwisata. Penghargaan kepada kelompok masyarakat akan hasil cipta tersebut menjadi penting untuk mendorong masyarakat lebih inovatif atau kreatif. Selain itu, lomba kreatifitas teknologi yang berbasis offline juga perlu didorong karena program ini memungkinkan pemerintah mendapatkan hasil secara langsung dari karya anak bangsa yang dapat dimanfaatkan secara langsung oleh pemerintah daerah.

Pemerintah daerah seharusnya tidak semata-mata bergantung pada inovasi dan kreasi masyarakat di bidang teknologi. Pemerintah dengan kemampuan dana atau ketersediaan dana yang diberikan seharusnya menganggarkan atau merencanakan program teknologi berbasis teknologi online dan offline. Di beberapa kabupaten dan kota di Sulawesi Selatan, program ini telah dijalankan. Pemerintah Kota Makassar misalnya, telah membuat suatu software atau sistem berbasis online dimana wisatawan dapat melihat berbagai kegiatan kepariwisataan yang dilaksanakan oleh pemerintah daerah. Di Kabupaten Maros Provinsi Sulawesi Selatan, Dinas pariwisata telah membuat suatu sistem software berbasis offline yang memungkinkan masyarakat atau pengunjung menggunakan informasi tersebut secara offline. Meskipun hal ini nampaknya kurang efektif secara penggunaan, sistem ini seharusnya dimanfaatkan secara nyata karena menggunakan dana dari pemerintah.

Terdapat beberapa cara atau pendekatan yang dapat dijalankan oleh pemerintah untuk mendukung pariwisata berbasis go digital yang diuraikan sebagai berikut:

1. Pemerintah menisiasi program teknologi informasi berbasis online dan offline yang akan dikerjakan atau dijalankan oleh pemerintah itu sendiri. Kemampuan 
staf yang mengetahui teknologi dapat diperbantukan untuk memaksimalkan program tersebut.

2. Kerjasama antara pemerintah dan industri pariwisata (pengusaha) merupakan strategi penting untuk mendapatkan informasi mengenai kebutuhan wisatawan dalam perspektif wisatawan dan industri pariwisata. Industri pariwisata adalah mereka yang bersentuhan langsung dengan pengguna atau pelanggan (user) sehingga mereka mengetahui secara mendalam kebutuhan wisatawan dan bagaimana sistem tersebut dikembangkan berdasarkan prinsip kerjasama dengan industri pariwisata. Industri pariwisata (pengusaha) perlu memberikan informasi kepada pemerintah mengenai usaha mereka dan bagaimana mereka bekerja. Hal ini akan memudahkan pemerintah menginput informasi yang akan disimpan dalam sisten berbasis online dan offline.

3. Pemerintah bersama berbagai elemen atau kelompok masyarakat dapat menciptakan program tersebut. Sebagaimana diuraikan sebelumnya, bahwa kompetisi yang sifatnya melibatkan masyarakat akan mendorong masyarakat akan makna dan arti penting pariwisata. Masyarakat di sekitar daya tarik wisata dapat dimanfaatkan atau didorong sebagai pelaku atau fasilitator pemanfaatana teknologi berbasis online dan offline.

\section{SIMPULAN}

Pemerintah Kota Parepare dan Kabupaten Bone (melalui Dinas Pariwisata) telah mengupayakan dan melaksanakan berbagai program kerja dalam mendorong peningkatan kunjungan wisatawan dan pengelolaan destinasi wisata. Sinergi pentaheliks pariwisata yang terdiri dari akademisi, pengusaha, pemerintah, masyarakat dan media juga telah dibangun meskipun program kerja bidang pariwisata lebih dominan didesain dan dilaksanakan oleh pemerintah daerah. Akademisi di tingkat daerah sangat dibutuhkan dalam membantu pemerintah daerah mengelola dan mengembangkan destinasi wisata. Melalui tugas penelitian dan pembimbingan kepariwisataan, mereka akan berkontribusi dalam pariwisata daerah serta membangun sinergi dengan pemerintah dan kelompok masyarakat lainnya.

Pengusaha bidang pariwisata telah mulai bermunculan meskipun dalam realita, pemahaman akan pentingnya karyawan dengan sistem kompetensi belum sepenuhnya dijalankan. Sinergi antara pemerintah dan pengusaha perlu dikembangkan melalui pemberian regulasi dan kesadaran pengusaha menjalankan usaha yang berpihak ke masyarakat dan taat pada regulasi yang ada. Masyarakat (khususnya mereka yang tinggal di sekitar daya tarik wisata) perlu diajak memahami arti pariwisata dan bagaimana menciptakan usaha kreatif bidang pariwisata. Hal ini juga perlu ditunjang dengan kesiapan media bersinergi dengan berbagai unsur pentaheliks melalui peran promosi dan edukasi ke masyarakat.
Sinergi pentaheliks pariwisata di dua destinasi tersebut tidak terlepas dari tantangan/hambatan atau faktor-faktor. Di satu sisi, otonomi daerah menjadi pendorong bagi daerah untuk kreatif dan inovatif dalam mengembangkan destinasi. Di sisi lain, otonomi daerah dapat melemahkan sinergi atau koordinasi jika dipahami sebagai hak atau otoritas daerah mengatur wilayahnya tanpa koordinasi dengan berbagai tingkatan pemerintahan. Penempatan staf yang tidak sesuai bidangnya (misalnya pariwisata) menjadi contoh konsekuensi dari otonomi daerah karena ada unsur politik. Selanjutnya, kesadaran masyarakat mengenai pariwisata masih lemah sehingga sinergi dibutuhkan upaya yang maksimal dalam hal koordinasi. Penguasaan teknologi dan kreatifitas staf di lingkungan Dinas Pariwisata daerah dalam manajemen destinasi wisata masih menjadi kendala dalam membangun sinergi pentaheliks pariwisata.

Penelitian ini merekomendasikan tiga model alternatif yang dapat diterapkan di Kota Parepare dan Kabupaten Bone. Model pertama menekankan pentingnya implementasi tata kelola destinasi (DMO) model pemerintah. Pemerintah menjadi pemimpin (leader) dalam membangun sinergi berbagai unsur pentaheliks pariwisata. Kedua, kawasan wisata dan ikon unggulan dapat menjadi model percontohan pengelolaan destinasi wisata. Ketiga, model pengelolaan pariwisata berbasis go digital adalah langkah strategis penting yang perlu diimplementasikan oleh pentaheliks pariwisata di destinasi wisata. Strategi go digital ini dapat melibatkan berbagai unsur pentaheliks pariwisata melalui sinergi yang terbangun. Strategi ini pula dapat mendukung terciptanya sistem connectivity yang memungkinkan penguatan sinergi antar lembaga

\section{UCAPAN TERIMAKASIH}

Ucapan terima kasih kepada Politeknik Pariwisata Makassar atas dana penelitian tahun 2017.

\section{DAFTAR PUSTAKA}

Altinay, L. \& Paraskevas, A. (2008), Planning Research in Hospitality and Tourism, Burlington: ButterworthHeinemann.

Arikunto, S. (2002), Metode Penelitian, Jakarta: Rineka Cipta.

Arman, H.S., Achsani, N.A., \& Fauzi, A. (2016). Analisis Sektor Strategis Pulau Sulawesi, Jawa Timur dan Kalimantan Timur. Sosiohumaniora, 18, (2) 97107.

Babbie, E.R. (2007). The Practice of Social Research, Belmont: Thomson.

Belsky, J. (2004). Contributions of Qualitative Research to Understanding the Politics of Community Ecotourism. Dalam Phillimore, J. dan Goodson, 
L. Editor. Qualitative Research in Tourism: Ontologies, Epistemologies and Methodologies. New York: Routledge. 273-291.

Bornhorst, T., Ritchie J.R. \& Sheehan, L. (2010). Determinants of Tourism Success for DMOS \& Destinations: An Empirical Examination of Stakeholders' Perspectives. Tourism Management (31): 572-589. doi:10.1016/j.tourman.2009.06.008

Bramwell, B. \& Lane, B. (2000). Collaboration and Partnership in Tourism Planning. Dalam Bramwell, B. dan Lane, B. Editor. Tourism Collaboration and Partnerships: Politics, Practice and Sustainability. Clevedon: Channel View Publications. 1-19.

Byrd, E.T. (2007). Stakeholders in Sustainable Tourism Development and Their Roles: Applying Stakeholder Theory to Sustainable Tourism Development, Tourism Review, 62, (2), 6-13.

Cooper, C. \& Hall, C.M. 2008, Contemporary Tourism: An International Approach, Oxford: Elsevier.

Currie, R.R. (2009). Determining Stakeholders for Feasibility Analysis. Annals of Tourism Research 36, (1): 41-63. doi:10.1016/j.annals.2008.10.002

Esu, B.B. \& Ebitu, E. (2010). Promoting an Emerging Tourism Destination. Global Journal of Management and Business Research. 10, (1), 21-28.

Flick, U. (2004). What is Qualitative Research? An Introduction to the Field. Dalam Flick, U. Kardorff, E.v. dan Ines, S. Editor. A Companion to Qualitative Research. London: SAGE. 3-12.

Flick, U. (2007), Designing Qualitative Research, London: SAGE.

Getz, D. \& Timur, S. (2005). Stakeholder Involvement in Sustainable Tourism: Balancing the Voices. Dalam Theobald, W. F. Editor. Global Tourism. Amsterdam: Elsevier. 230-247.

Hatch, J.A. (2002), Doing Qualitative Research in Education Settings, New York: State University of New York.

Haugland, S.A. (2011). Development of Tourism Destinations: An Integrated Multilevel Perspective. Annals of Tourism Research. 38, (1), 268-290. doi:10.1016/j.annals.2010.08.008

Indira, D., Ismanto, S.U. \& Santoso, M.B. (2013). Pencitraan Bandung Sebagai Daerah Tujuan Wisata: Model Menemukenali Ikon Bandung Masa Kini. Sosiohumaniora, 15, (1), 45-54.

Jamal, T. \& Stronza, A. (2009). Collaboration Theory and Tourism Practice in Protected Areas: Stakeholders, Structuring and Sustainability. Journal of Sustainable Tourism. (17) 2: 169-189. http://dx.doi.org/10.1080/09669580802495741
Jamal, T. \& Getz, D. 1995. Collaboration Theory and Community Tourism Planning. Annals of Tourism Research. 22: 186-204.

Junaid, I \& Hanafi, H. (2016). Ikon Habibie-Ainun, Strategi Inovatif Dalam Mengembangkan Pariwisata Di Kota Parepare, Sulawesi Selatan. JUMPA 3, (1), 127-142. https://ojs.unud.ac.id/index.php/jumpa/ article/view/23048

Junaid,2015. Model Implementasi DestinationManagement Organization (DMO) Di Kota Makassar, Provinsi Sulawesi Selatan. Jurnal Kepariwisataan, 9, (2), 29-47. https://jurnal.poltekpar-makassar.ac.id/ index.php/tourism/article/view/3

Kayat, K. (2008). Stakeholders' Perspectives Toward a Community-Based Rural Tourism Development. European Journal of Tourism Research. 1, (2): 94111.

Morrison, A. (2012). Destination Management and Destination Marketing: The Platform for Excellence in Tourism Destinations.

Pattanaro, G. (2014). Success Factors for Collaborative Destination Marketing. Dalam Mariani, et al. Editor. Tourism Management, Marketing, and Development: The Importance of Networks and ICTS. New York: Palgrave Macmillan. I, 221-238.

Park,O.J.,Lehto,X.Y.\&Morrison,A.M.(2008).Collaboration Between CVB and Local Community in Destination Marketing: CVB Executives' Perspective. Journal of Hospitality \& Leisure Marketing. 17, 3-4. doi:10.1080/10507050801985047

Presenza, A. \& Cipollina, M. (2010). Analysing Tourism Stakeholders Networks. Tourism Review, 65, (4), 17-30. DOI 10.1108/16605371011093845

Priyambodo, T.K. (2005). Implementasi Web-Service Untuk Pengembangan Sistem Layanan Pariwisata Terpadu. Seminar Nasional Aplikasi Teknologi Informasi 2005. http://journal.uii.ac.id/Snati/ article/view/1311

Ritchie, J., Spencer, L. \& O’Connor, W. (2003). Carrying out qualitative analysis. Dalam Ricthie, Jane dan Lewis, Jane. Editor. Qualitative Research Practice: A Guide for Social Science Students and Researchers. London: SAGE. 219-262.

Shaw, S. (2007). Ethnic quarters in the cosmopolitancreative city. Dalam Richards, G., dan Wilson, J. Editor. Tourism, creativity and development. New York: Routledge. 189-200.

Tuohino, A. \& Konu, H. (2014). Local Stakeholders' View About Destination Management: Who are Leading Tourism Development? Tourism Review. 69, (3), 202-215. http://dx.doi.org/10.1108/TR-062013-0033 